\title{
Analysis of Covid-19 Situation in Udupi District, Karnataka, South India
}

Pallavi ${ }^{1}$, Gulappa Devagappanavar ${ }^{2 *}$

${ }^{1}$ Master of Public Health Scholar, Department of Public Health. India.

${ }^{2}$ Guest Faculty in School of Environmental Science, Public Health and Sanitation Management, India.

*Corresponding Author: Gulappa Devagappanavar, Guest Faculty in School of Environmental Science, Public Health and Sanitation Management. India.

Received date: April 20, 2021: Accepted date: May 03, 2021: Published date: October 9, 2021

Citation: Pallavi, Devagappanavar G (2021) Analysis of Covid-19 Situation in Udupi District, Karnataka, South India . J. of Clin Case Rep and Stu 2(6); DOI: 10.31579/2690-8808/075

Copyright: (C) 2021 Gulappa Devagappanavar. This is an open access article distributed under the Creative Commons Attribution License, which permits unrestricted use, distribution, and reproduction in any medium, provided the original work is properly cited.

\section{Abstract:}

Background: COVID 19 originated in Wuhan city and rapidly spread to various countries. The first case from India was notified on $30^{\text {th }}$ January at Kerala state. Karnataka identified with COVID cases in the month of March. First case in Udupi notified on 24/03/2020. At the end of August 30 the cases were reached to 11598 . Present study aimed to study the trends and pattern of Covid-19 in one of the coastal region of Karnataka i.e. in Udupi district.

Objectives: 1) Analyze the trend and pattern of COVID 19 cases at Udupi district. 2) Calculate the incidence, Prevalence, Case Fatality rates and Competed

Methodology: Data is obtained from media bulletin released by the Dept.of health and family welfare Karnataka. Udupi district was chosen for study and data is analyzed through MS excel and case fatality rate, Completed case fatality rate, patient recovery rate were calculated and expressed in graphs

Result: The case load in increased exponentially but growth rate is dropping down as month advances. Prevalence of the cases expressed in Attack rate, CFR, CCFR and PRR. In the month of April attack rate is 1.43 per lakh population, that increased to 88 cases per lakh population.by May, This indicated high susceptible population getting infected. Then it got stabilized around 2-6 folds per month and At the end of August 30 the cases were reached to 11598.In August month fatality rate reaches at peak level with value of 0.9 . Total growth in CFR from June to August is $89 \%$. The cases were high in rainy season when compare to summer season. It indicates climate has direct effect on the Covid 19 spread in Udupi district

Conclusion: The case load in increasing exponentially but growth rate is dropping down as month advanced in Udupi district indicates better management of cases. Cases got reduced after imposing lockdown in district. Preventive measures and social distancing played an important role in reduction of case load in district.

Keywords: COVID -19, Attack rate, Recovery rate, Death rate, trends and patterns of Covid

\section{Introduction}

According to WHO corona virus disease (COVID-19) is an infectious disease caused by corona virus which is newly discovered virus. It will cause mild to moderate respiratory illness. It spreads through droplet cough, saliva and nasal discharge. Common symptoms are fever, tiredness and dry cough. Less common symptoms are sore throat, pains and aches, diarrhoea, conjunctivitis, headache, rash on skin, loss of taste or smell and in severe cases breathing difficulty, chest pain and loss of movement or speech can be observed.

Taxonomically corona virus is a member of corona viridae family under nidovirules order. Corona is specialized by crown type spikes on outer layer of virus since it was named as coronavirus. Corona virus is 65$125 \mathrm{~mm}$ in diameter and has single-stranded RNA. Coronavirus family is subdivided in alpha, beta, gamma and delta. Generally all type of Corona viruses encompassed with particular genes in ORF1 downstream regions that encode proteins for nucleocapsid, viral replications and spike formations. The spikes made up of glycoprotein responsible for attachment as well as entry of virus to host cells (1).

The viruses such as SARS-COV, H1N1 2009, H5N1 influenza etc were cause acute respiratory distress syndrome and pulmonary failure may cause death. Till 2002 it was believed that these viruses affect only animals but not human beings. This belief got eliminated when severe 
acute respiratory syndrome led to outbreak in China resulted from SARS$\mathrm{CoV}$ in 2002 (2). Initially SARS emerged in Guangdong of China, then rapidly spread to around the world with greater than 8000 infected people and 776 deaths (1).

After a decade (2012) another type of novel corona virus named MERS $\mathrm{CoV}$, which affected the Middle East country. By comparing structure of SARS-CoV and MERS-CoV, one can observe that many structural similarities and receptor specificity among both (3). MERS CO-V affected Saudi Arabian nationals. According to World health organization reports, MERS-CoV infected greater than 2428 people and 838 deaths.

MERS- $\mathrm{CoV}$ is member of beta corona virus subgroup and phylogenetically diverse from other human-CoV. The MERS CoV starts with mild symptoms of upper respiratory injury; if it progresses further it might result in severe respiratory diseases. Similar to SARS- Cov, individual infected by MERS-CoV experience pneumonia, followed by acute respiratory Disease Syndrome (ARDS) and renal failure. (1)

At the end of the year 2019, outbreak of novel corona virus has originated at Wuhan city of China. The virus belongs to beta group of corona viruses. Chinese researchers named this virus as 2019 novel coronavirus. World Health Organization (WHO) also announced the name of the disease with short name as corona virus disease (COVID 19) (4). Later International Committee on Taxonomy of viruses named the virus as severe acute respiratory syndrome coronavirus-2 (SARS CoV 2).

According to past history, MERS and SARS are originated from bats and camels. In case of SARS CoV2, there was not a proper evidence of diseases origin. Some researcher had mentioned that, virus may originate from bats and some other live animals since existence of bats and live animals at Wuhan seafood market (5).

Estimation rooted on early outbreak data from $31^{\text {st }}$ December 2019 to 28 January 2020 at China resulted that reproduction number for Covid 19 was 6.28 and doubling time was 6.4 days (6) .The cases were spread rapidly worldwide (outside the china) through international travelling.Corona virus rapidly spreads across the world. On $30^{\text {th }}$ January WHO announced covid 19 outbreak as international concern public health emergency (7). On $11^{\text {th }}$ February 2020 the WHO mentioned in its report that there were 43103 people affected globally by covid- 19 .

As on $24^{\text {th }}$ August 2020, there were 23311719 cases of COVID 19 and 806410 deaths were reported to WHO from worldwide. On $24^{\text {th }}$ August in India total 3106348 confirmed cases with 57542 deaths were reported (8).

The first case from India is notified on $30^{\text {th }}$ January at Kerala state. Within 3 days active cases increases to three. These cases are linked with student who had returned from Wuhan, China. Thereafter none of the cases reported in the month of February. Then COVID 19 spread to remaining states in India. First stage of outbreak in India began in the second week of March. The peak value of CFR per closed was $27.38 \%$ on 2ne April and value reduced to $23.27 \%$ on April $14^{\text {th }}$. As on April 14 national CFR per total is $3.32 \%$ where as CRR per total is $11 \%$ and $76.72 \%$ per closed cases. Government extended the lockdown till May $3^{\text {rd }}$ as lockdown -2in India. COVID 19 spread in India at the end on initial lockdown by April $14^{\text {th }}$ indicates total 10815 cases, 9272 active cases, and 1190 cured and 353 death in 31 states/UTs. The larger number of cases reported in Maharashtra (2337), followed by Delhi (1510) and Tamil Nadu (1173) (9).

As on $22^{\text {nd }}$ march there are 360 cases with 7 deaths in India has reported to world health organization (WHO). Covid-19 cases rapidly spread to 23 states/UTs. As of march $22^{\text {nd }}$ worst affected states are Maharastra (67), Kerala (52), Delhi (29), Uttar Pradesh (27) and Karnataka (26) (10). Under disaster management act PM Narendra Modi advised lockdown in entire country for 21 days from March $25^{\text {th }}$ to April $14(11)$.

The first case in Karnataka is reported on March $8^{\text {th }}$. Lockdown begins during $24^{\text {th }}$ March in in the state. Cases increases and reached 40 on $24^{\text {th }}$ March (12). Five worst affected districts during $1^{\text {st }}$ phase of lockdown are BBMP, Mysore, Belagavi, Kalburgi and Bagalkot(12). Karnataka government extended the lockdown from April 14 $4^{\text {th }}$ to $21 / 04 / 2020$ (13). Further extension of lockdown period to next two weeks with effect from 04/05/2020(14). After that they expanded lockdown period till 30/05/2020 (15). Govt took initiative to unlock the outside of containment zones and extension of lockdown in containment zones (16).

With this background of covid 19, this study analyses the covid 19 data in Udupi district of Karnataka which is a coastal place and has good literacy level. This study aimed to analyze the trends of covid 19 at Udupi district. First case in Udupi notified on 24/03/2020. Cases in Udupi got exponential rise from the month of May 2020.

\section{Objectives:}

1) To Analyse the trend and pattern of COVID 19 cases at Udupi district. 2) To calculate the prevalence of COVID 19 cases in Udupi district, Karnataka.

3) To examine the death rate and discharge rate among COVID19 cases in Udupi district of Karnataka.

\section{Methods}

Study Design and data source: A cross sectional analysis of Covid data of Udupi district was conducted for the period for 5 months from April 2020 to August 2020. The secondary data were obtained fromCOVID-19 information portal media bulletin of health and family welfare Karnataka website which include variables such as Positive cases by daily basis Total positive cases, Discharge cases in daily basis, Total discharge cases, Total active cases, and No. of deaths daily basis.

Inclusion criteria: All positive cases from April to August 2020 in Udupi district were included in study analysis.

Data analysis: Data on the basis of all variables were recorded and calculated the case fatality rate, attack rate, confirmed case fatality rate and patent recovery rate. Trends and pattern of Covid 19 in different month were analyzed and results were expressed in graphs.

\section{Results}

\section{Different indicators of COVID-19 in Udupi district:}




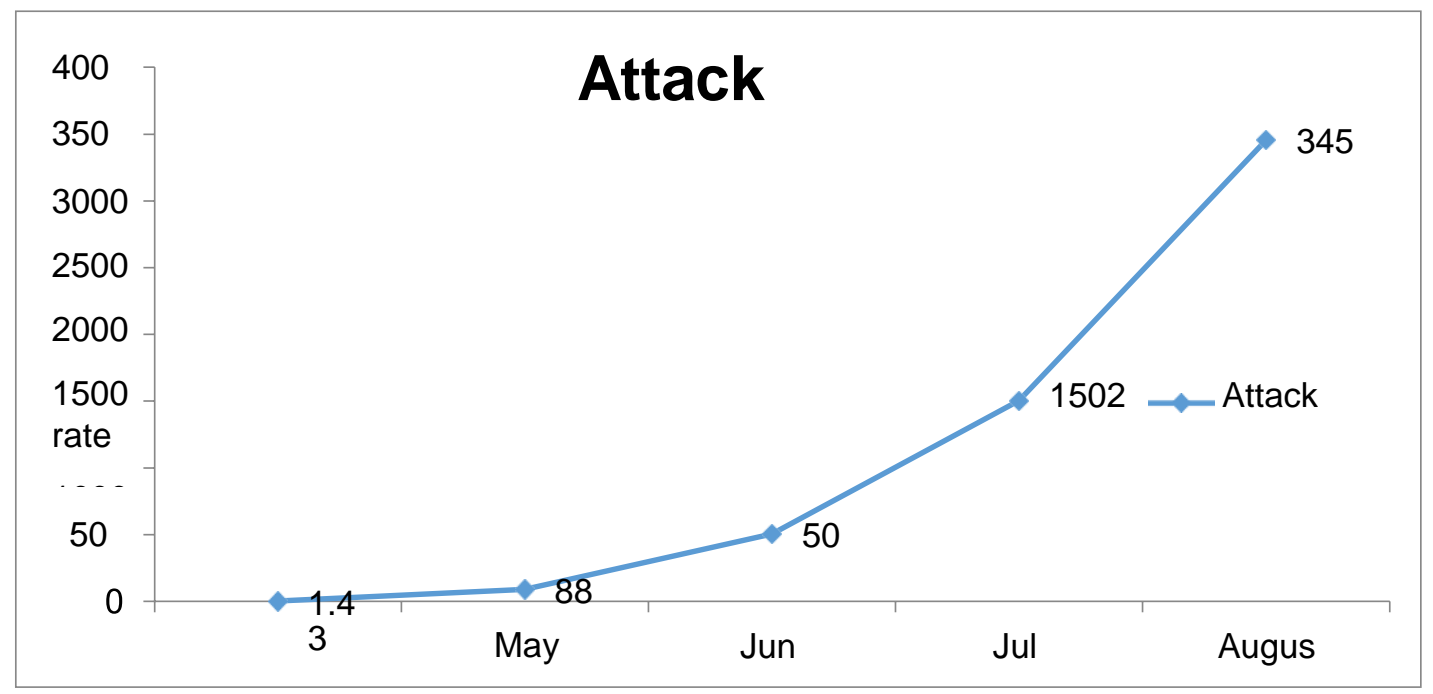

Figure 1: Attack rate of COVID cases

Attack rate: Number of casesper lakh population in each month is calculated (total confirmed cases by total population each month. (Entire population is at risk in Pandemic situation). Attack rate of COVID in Udupi has increased at faster rate in these 5 months. In the month of April attack rate is 1.43 per lakh population. In May month attack rate increased to 88 cases per lakh population. 62 times more than April indicating every primary case spread infection to 62 others. In June month there are 6 times more cases than previous month. After the initial secondary cases 62 per case, in subsequent months each case was spreading to another 5.7, 2.97and 2.3. Sudden rise in case load from April to May indicates high susceptible population to the virus that stabilized around 2-6 folds per month (figure 1).

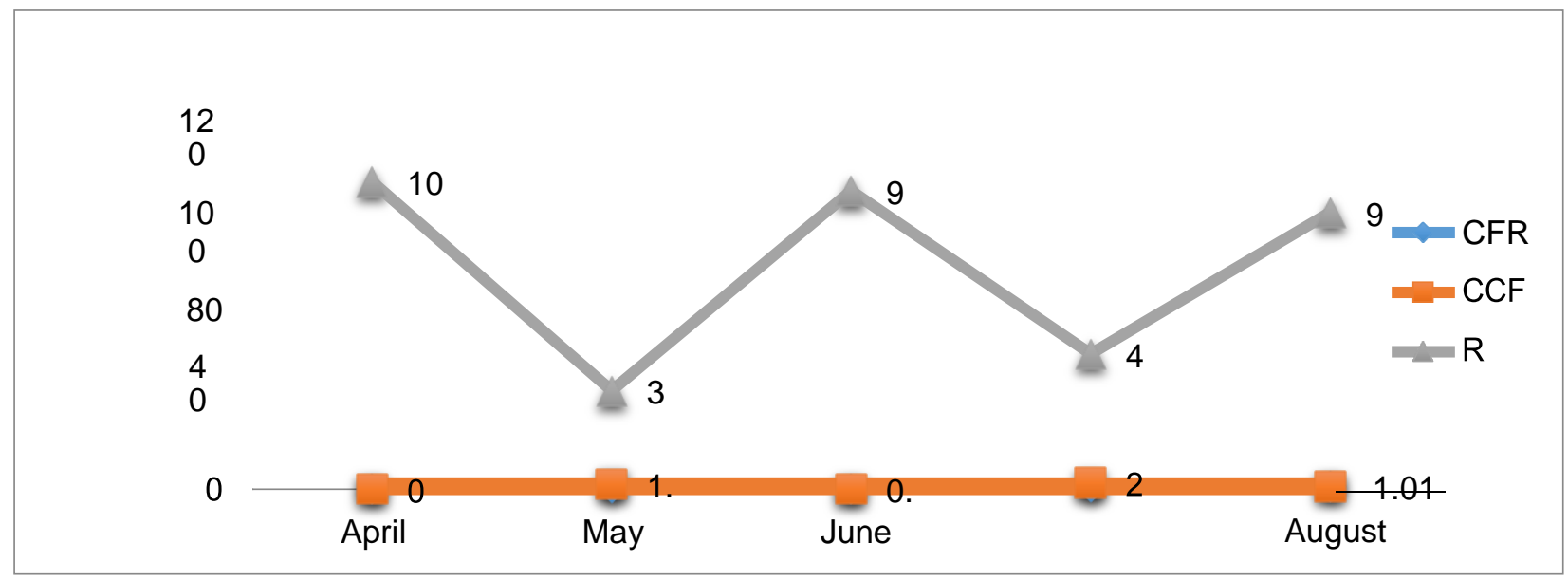

Figure 2: month wise CFR, CCFR and PRR in Udupi district

\section{Case Fatality rates at Udupi district:}

The line graph in figure 2 represents case fatality rate in five months. In first phase (April) case fatality rate is 0 which indicates there were no severe cases of death. In second month (May) CFR was 0.5.In third month (June) CFR was 0.1 -reduced by $80 \%$ from previous month. In fourth month (July) case fatality was 0.85 increases of $88 \%$. In August month fatality rate reaches at peak level with value of 0.9 . Total growth in CFR from June to August is $89 \%$. In Udupi district overall case fatality rate less than 1 throughout during April to August months (figure 2).

\section{Completed Case Fatality rate in Udupi district:}

CCFR provides complete picture actual care and outcome. CCFR is more valid result which takes account of discharged cases as denominator. Month on as the number of cases complete their history end in deaths or cure. When compared to CFR where denominator is all cases the fate of active cases, we do not know yet. The range of TR/PCR turning negative is from 10- days to 3 months among more severe cases. The average time taken is 17 days.

\section{Patient recovery rate in Udupi:}

Patient recovery rate indicates effectiveness of case management in District. At the initial stage of COVID case there exist hundred percent recovery rates i.e. in April 2020. It indicates that case load is very less in number; they were mild cases and well managed by health facilities in Udupi.PRR was in the month of May reduced by $212 \%$ which implies the poor management of cases in May. In June again the patient recovery got increased by $67 \%$ than previous month. July month marked with 2 folds less recovery rate than previous month. In August again recovery increased by $51 \%$ than previous month. (Figure 2 ). 


\section{Month Wise Total cases, Active cases, recovered cases and} death due to COVID:

The first case in Udupi district begins from $24^{\text {th }}$ March. This study analyzed the progress of disease from April to August 2020. In April only 3 cases And All 3 cases recovered. In the month of May sudden surge cases in total 187 total cases. Further in June again the cases increased to 1206 cases. This is 6 times more than that of previous month. The case load in increasing exponentially but growth rate is dropping down as month advances (Figure3).

In the context of active cases, in April there were no any active cases. In the month of May there was sudden increase in active cases to 123. June month represents with $17 \%$ increase in active cases than previous month. In July the case load increases in fast rate by $92 \%$. It states 13 times more case load than June. In August active case increased by $25 \%$. In July month the active case rose very high than other months. It may be due to poor case management during July (Figure3).

There was $100 \%$ recovered cases in April month is observed. In the month of May 63 recovered cases were recorded out of 187 total cases. The June month has $94 \%$ growth in recovery rate than May 2020. Further in July one can see $57 \%$ rises in recovery than previous month. There was still more increase in recovery cases is recorded in August (73\% growth than July).

Death due to COVID is increased as month advances. There was zero death recorded in April month. In May month only one death can be seen in district. 93\% sudden growth in number of Covid death is seen in July month than June 2020(29 recoveries). In August month death rises exponentially three times more than that of July. Case fatality also increased with case load. It may be due to lack of health care equipment and treatment in district (figure 3 ).

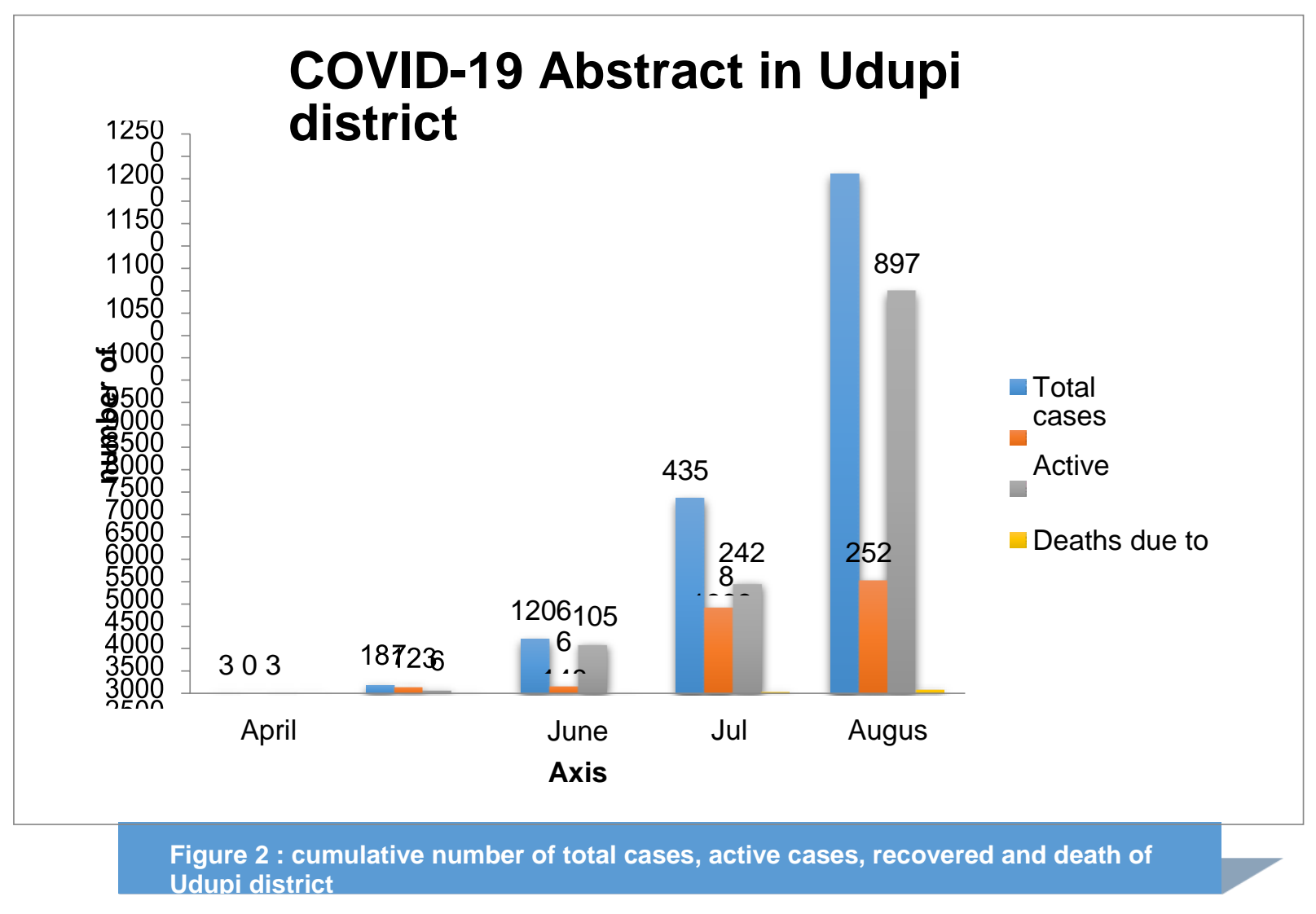

\section{Lockdown wise Trends of COVID at Udupi district:}

Figure 4 shows the cumulative number of cases during each lockdown and unlocking process at Udupi district. The first case in Udupi district recorded on 25 March. In first phase of lockdown confirmed case is 0 , which implies there was no confirmed cases were recorded since the Covid test result may delayed or inadequate laboratories and technologies. In second phase of lockdown (Lockdown2.0) cumulative cases were 3. In $3^{\text {rd }}$ phase of lockdown cases was three in number, indicates there may be break in viral transmission due to lockdown measures. In fourth phase the cases was 10, i.e. 3 times increase in case load from second phase it indicates 3 people infected per cases. In last phase of lockdown the cases increased rapidly 18 times more than $4^{\text {th }}$ phase. Sudden surge of cases from $3^{\text {rd }}$ phase to fifth phase of lockdown is 3 to 18 folds more than initial phases. This may be due to negligence of people towards the lockdown measures and urge of people to earn their livelihood.

Unlock measures took by government to resume the normal activities in district. The COVID surge got reduced as time advanced. The transmissions of virus reduced during unlock process of Udupi district. The viral transmission limited to 1 person per cases from unlock 1 to unlock 2 . Only 3 folds rise in infection transmission can observed from unlock 2 to 4 . This implies great reduction in viral transmission may be due to increased awareness among people and stability in immunity level considered (figure 4). 


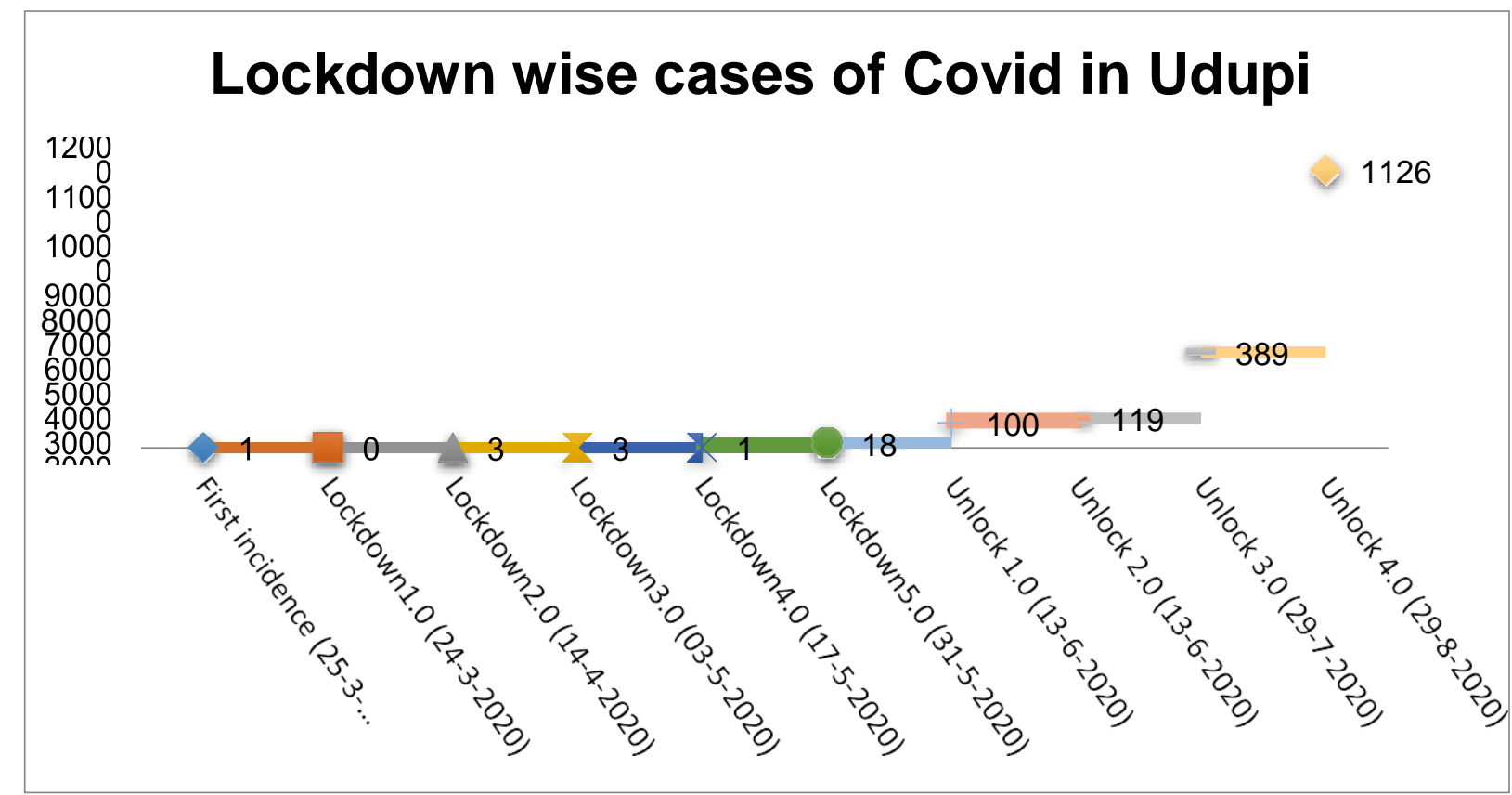

\section{Figure 3 : COVID confirmed cases in Udupi district, during and after lockdown}

\section{Week wise trends of COVID in Udupi district:}

In April month week wise cumulative record of cases shows that constant maintenance of 3 cases in all the 4 weeks. There is no additional number of cases throughout the month. Lockdown measures can be appreciable during April month (Figure 5).

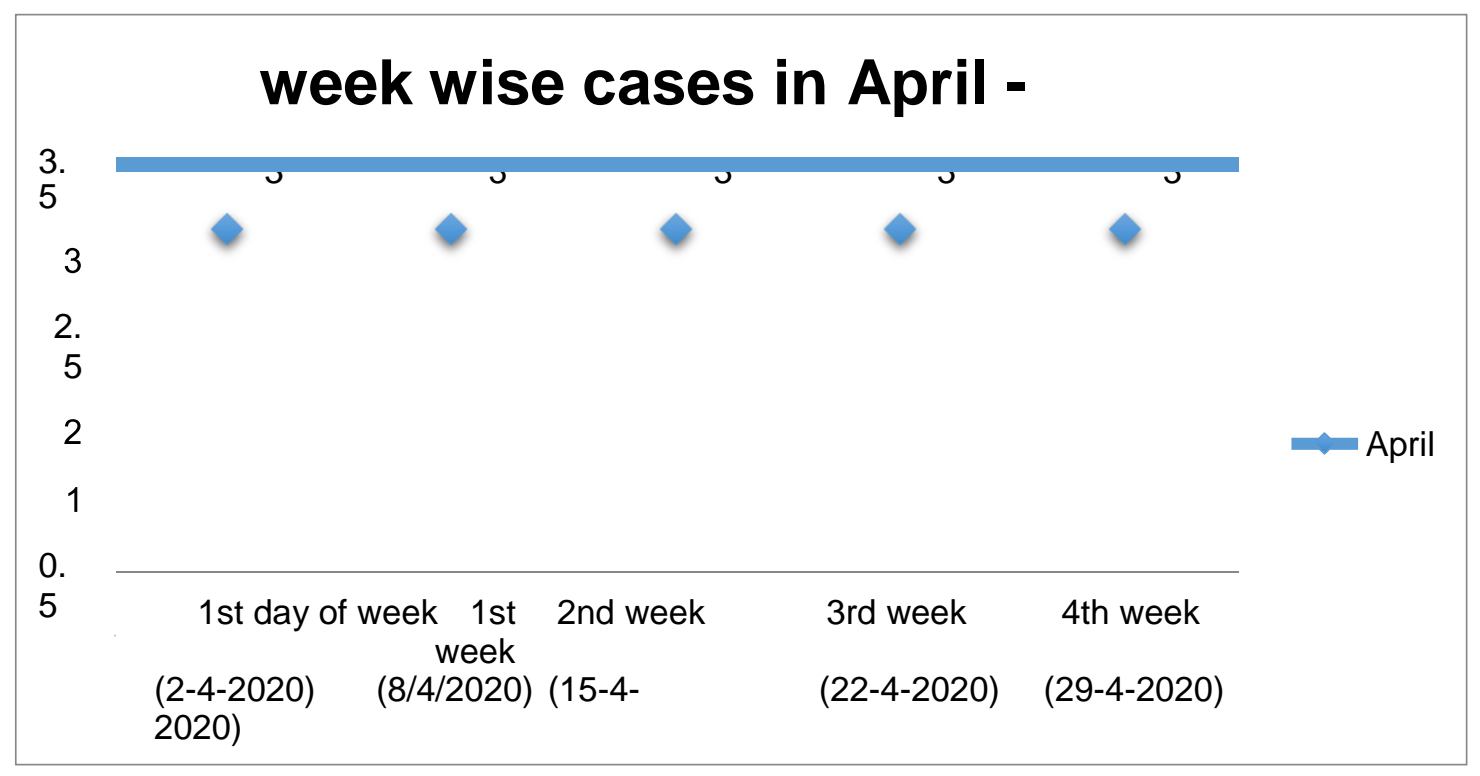

\section{Figure 5 : week wise distribution of COVID cases of April month in Udupi}

Figure 6 illustrates the week wise cumulative cases in May month. First two weeks of month is well maintained with 3 cases. Sudden rise in cases to 47 in third week i.e. additional 44 cases recorded in third week, 15 times greater than first 2 weeks. Every primary case spread virus to 15 others. In fourth week rapid growth of confirmed cases rose to 149, implies 102 cases increased this week. 2 folds greater than previous week. Even though the lockdown measures implemented last two weeks has greater number of cases recorded. Overall growth of Covid in May was $97 \%$ (Figure6). 


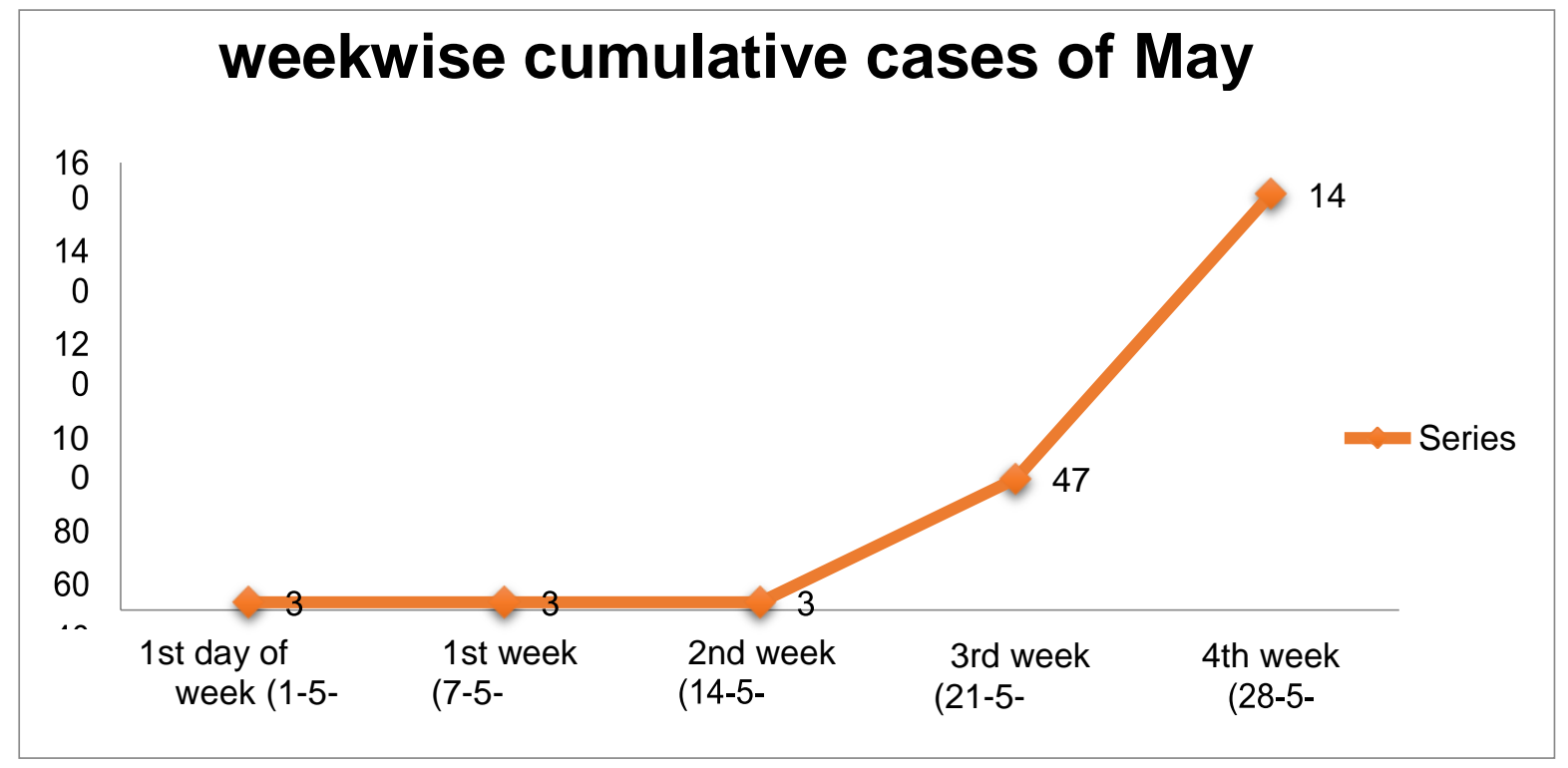

Figure 6 : week wise growth of COVID cases of May month in Udupi

First day of month recorded with 260 cases in June. At the end of the first week there were 642 additional cases recorded and cumulative cases become 902. 2.5 times more cases recorded at the end week. In the second week $12 \%$ increase from first week. 37 additional cases recorded in $3^{\text {rd }}$ week and 116 additional cases in $4^{\text {th }}$ week. Highest number of cases recorded in first week of the month. Following weeks after first week shows considerable reductions in growth of COVID. There was overall $78 \%$ growth in COVID cases in June 2020 (figure7).

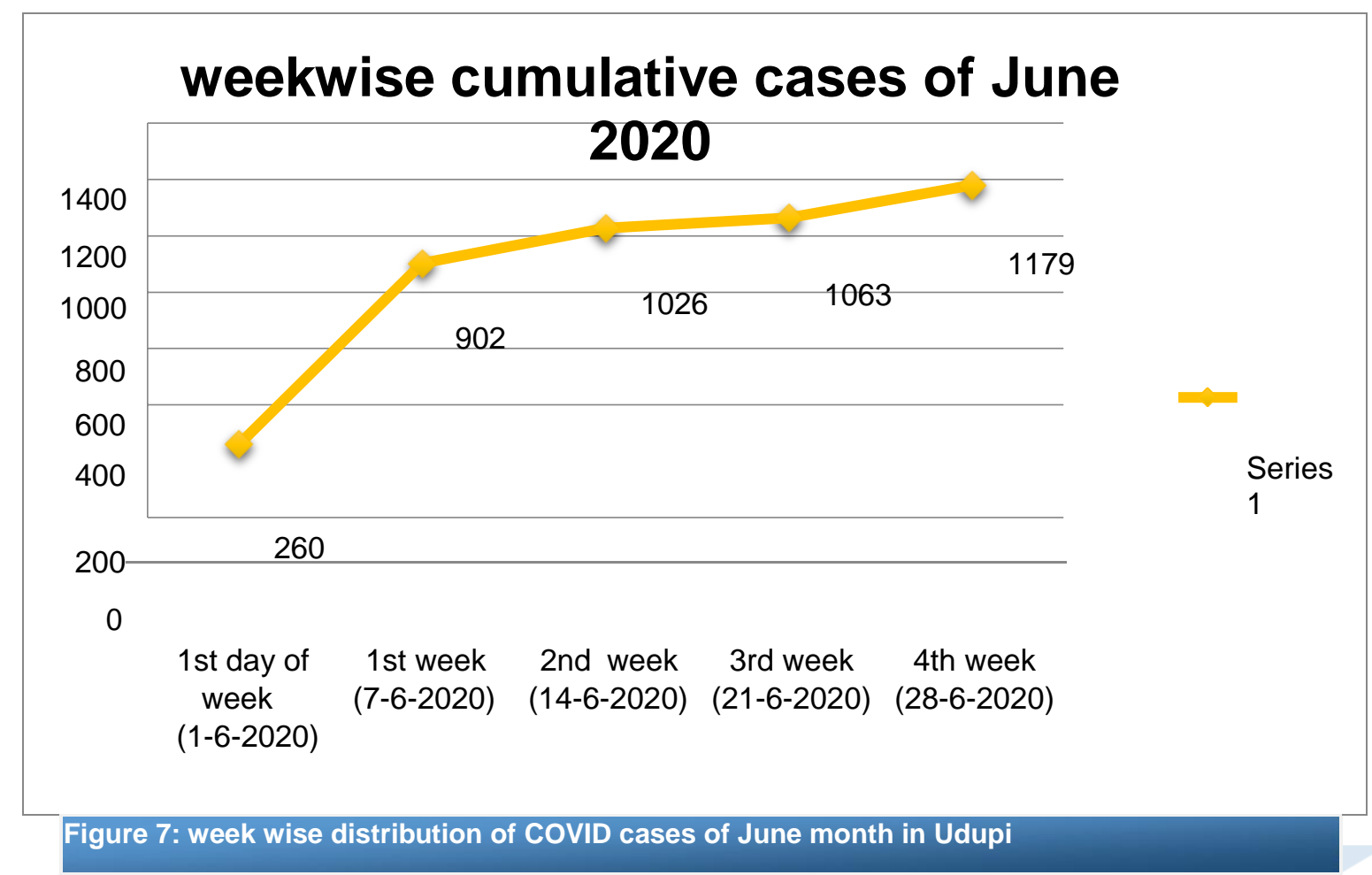

There were 1228 cumulative cases recorded in the first day of the month. Addition of 161 cases in first week and following subsequent weeks has addition of 346,586 and 1400 cases respectively. $4^{\text {th }}$ week has highest number of cases than others. Overall reduction from first week to $4^{\text {th }}$ week is $63 \%$ (Figure 8 ). 


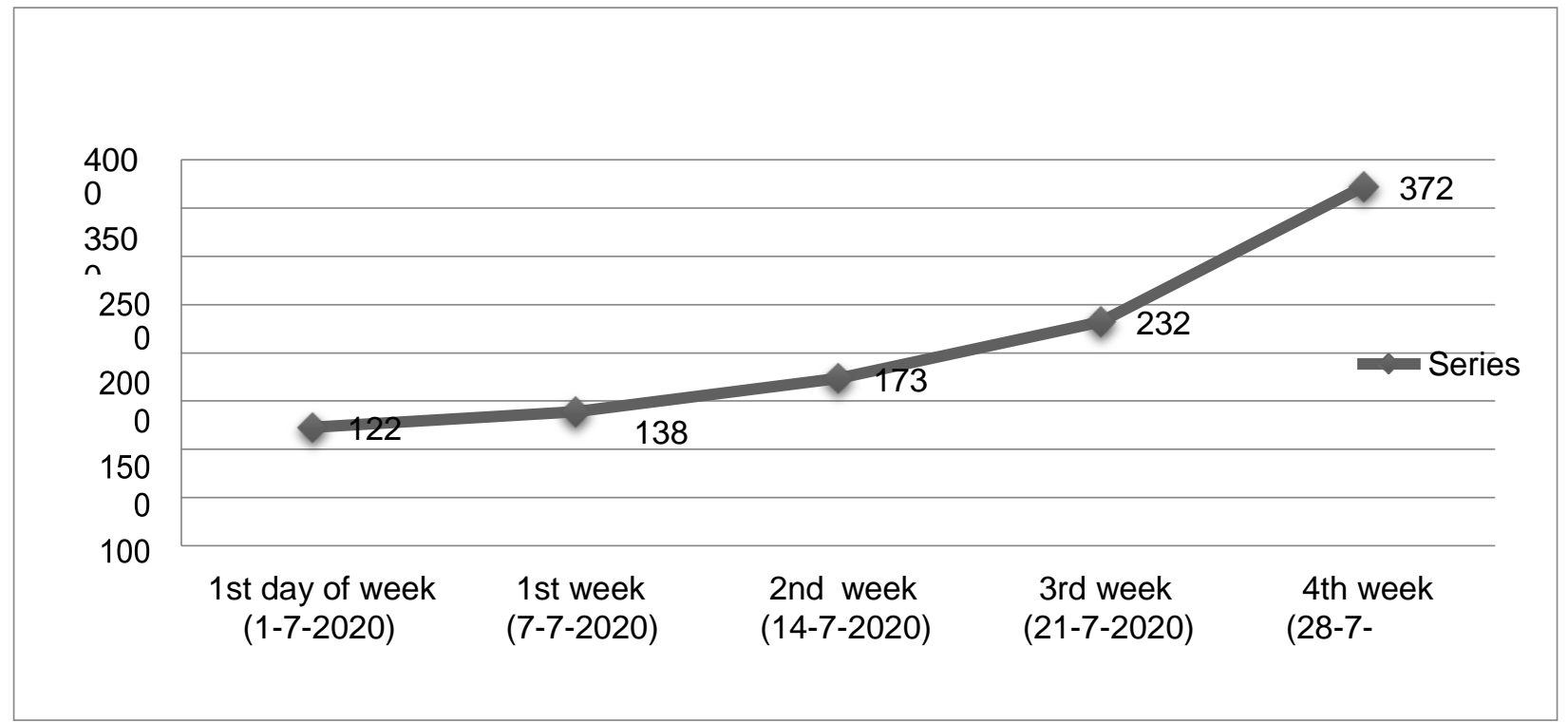

\section{Figure 8 : week wise growth of COVID cases of July month}

\section{in Uduni}

Figure 9 shows the cumulative case in week wise of August month. Highest surge of cases is recorded in $3^{\text {rd }}$ week of the month (addition of
2171 cases). Cumulative cases reached at peak level in August month. Overall growth rate in August month from first week to last week is $49 \%$.

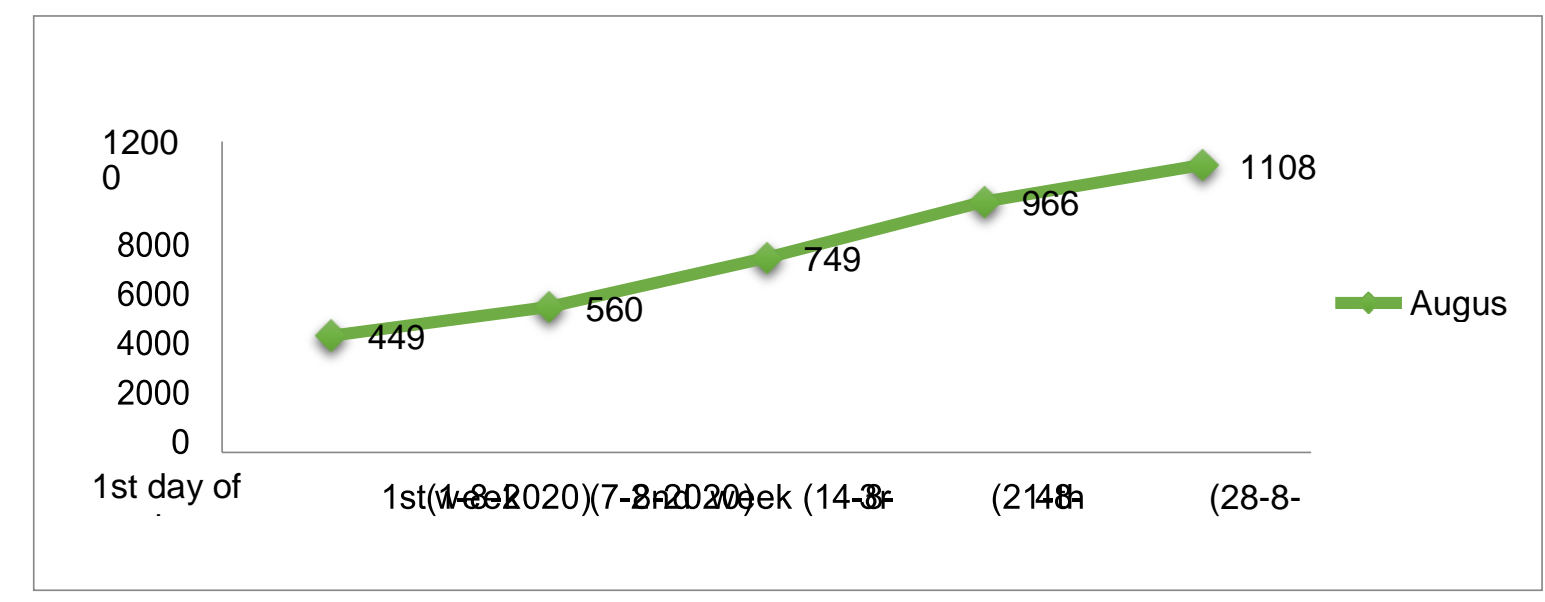

\section{Figure 9: week wise distribution of COVID cases of August} month in Udduni

The cases rose rapidly in these 5 months. In April there was o growth in number of case in all 4 weeks. In May there was 5 folds increase in disease transmission from first week to last week. After those next 3 subsequent months has $4.5,3$ and 2.5 folds greater COVID cases in $4^{\text {th }}$ weeks from first day of month. From this one can analyze that there were significant reduction in virus stability in transmission of disease from May to August. 


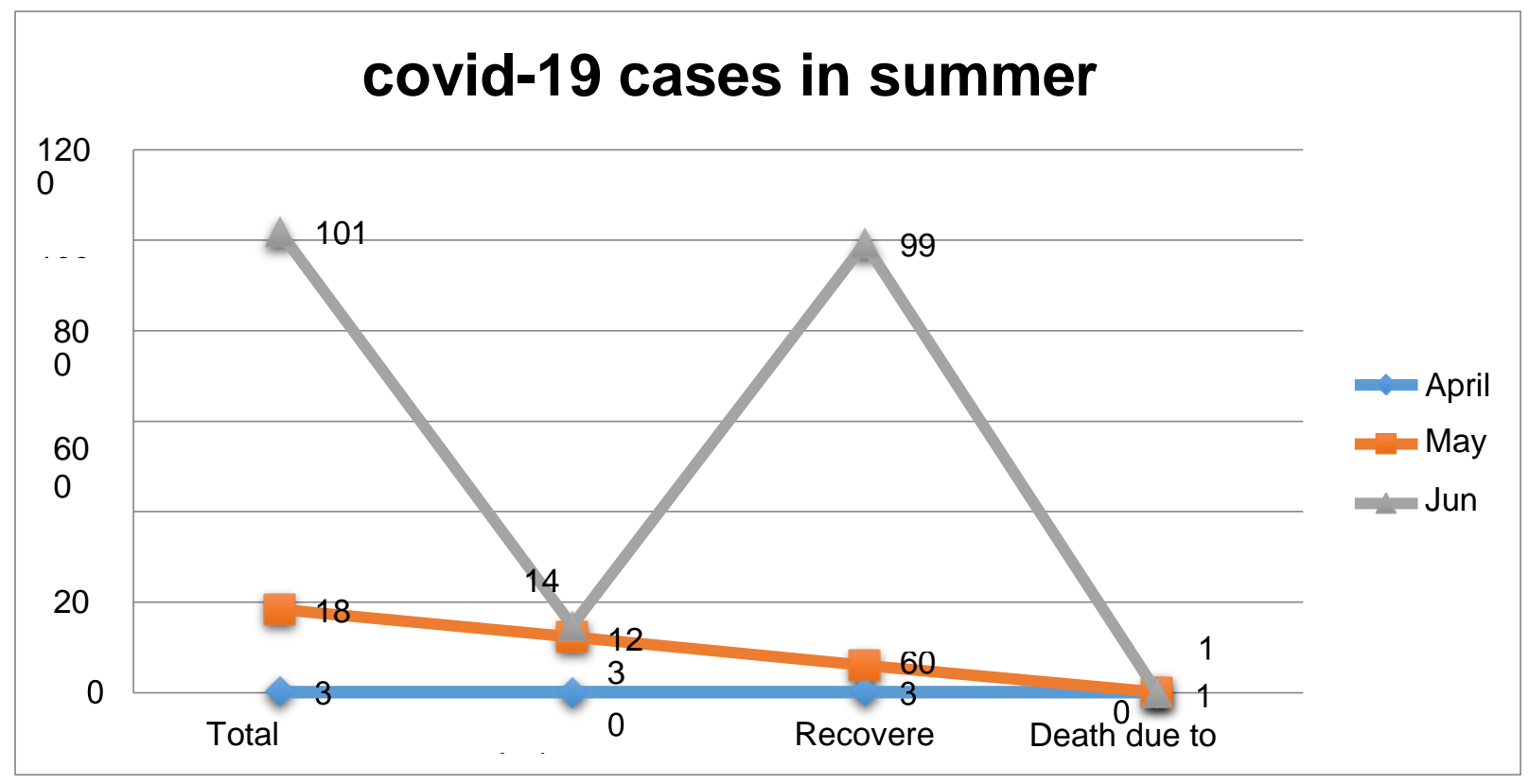

Figure 10: Covid 19 cases during summer season

Figure 10 represents covid 19 cases in summer season of April, May and June. In April there were less cases and in May it increased by 61 folds of April month. In June month the cases increased by 5 folds of that of
May month. It clearly indicates that cases got rose exponentially in May month even though there is a hot temperature.

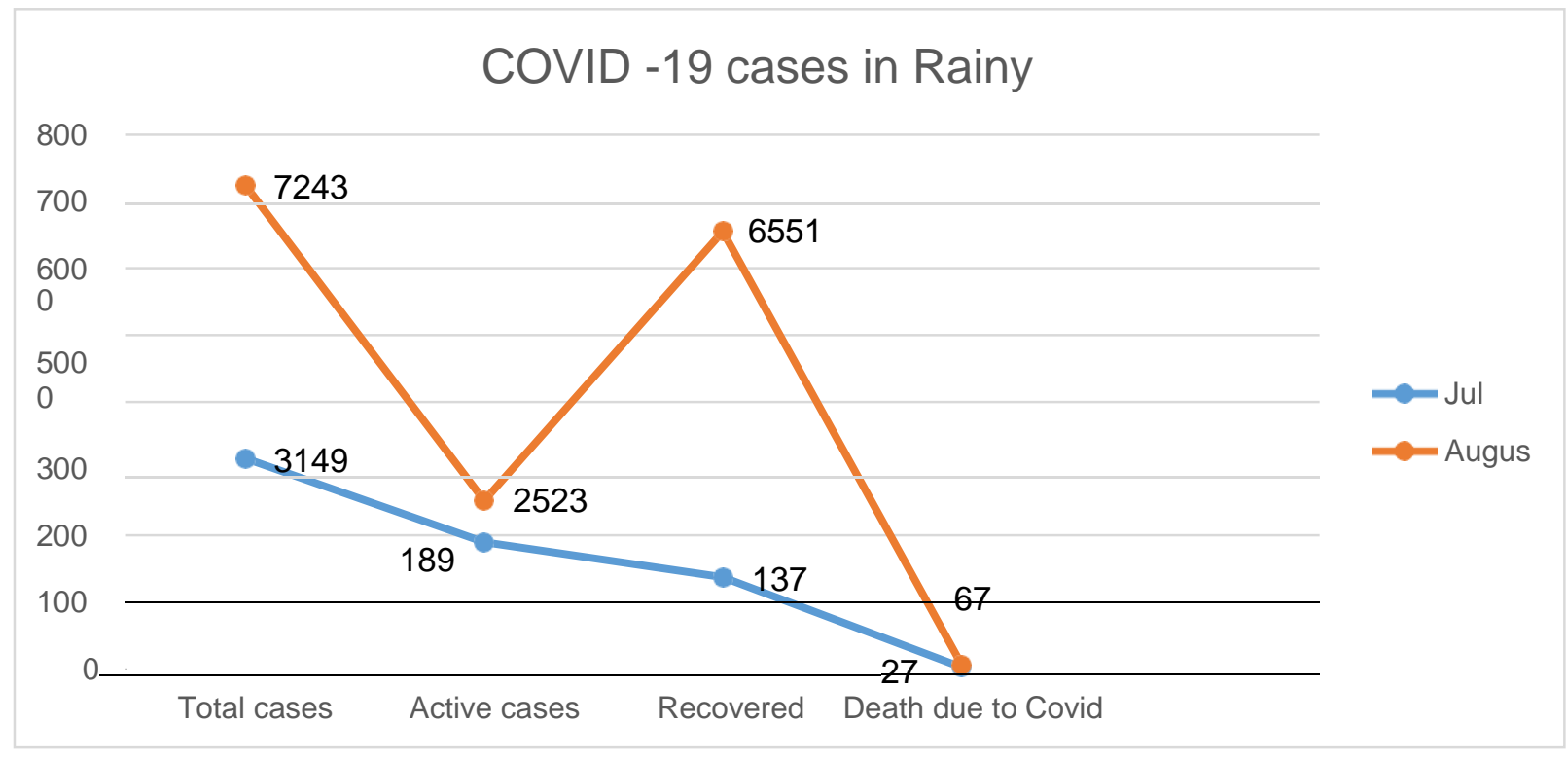

Figure 11: Covid 19 cases during Rainy season

Cases got increased from July to August. The cases were high in rainy season when compare to summer season. it indicates climate has direct effect on the Covid 19 spread in Udupi district.

\section{Discussion}

\section{Trends and pattern:}

In this analysis shows that the April month has only few cases raisedSimilar increase in incidence occurred throughout all districts of Andra exponentially in May month which 32 folds more than April month where as

Auctores Publishing - Volume 3(3)-075 www.auctoresonline.org in June again cases increased by 6 folds. Growth rate got reduced as month advanced.

A study conducted by the Ramanan Laxminarayan et al indicates the corona cases at Tamil Nadu and Andra Pradesh. An outbreak in Tamil Nadu began in April month and 1142 cases on $15^{\text {th }}$ May. Incidence of cases increased in Southern districts of Tamil Nadu by June and Northern District by August. 
Pradesh in June. Numerical and geographical extent of cases remained limited 6. during April and May(17).

\section{Conclusion}

The case load in increasing exponentially but growth rate is dropping down as

month advanced in Udupi district indicates better management of cases. Cases 7 .

got reduced after imposing lockdown in district. Preventive measures and

social distancing played an important role in reduction of case load in district. 8 .

\section{References:}

1. Shereen MA, Khan S, Kazmi A, Bashir N, Siddique R. (2020). COVID-19 infection: Origin, transmission, and characteristics of human coronaviruses. J Adv Res; 24:91-98.

2. Zhong NS, Zheng BJ, Li YM, Poon LLM, Xie ZH. et al. (2003)Epidemiology and cause of severe acute respiratory syndrome (SARS) in Guangdong, People's Republic of China. Lancet; 2003; 362(9393):1353-1358.

3. Wang N, Shi X, Jiang L, Zhang S, Wang D. et al. (2013). Structure of MERS-CoV spike receptor-binding domain complexed with human receptor DPP4. Cell Res; 23(8):986-993.

4. Report S. Novel Coronavirus (2019-nCoV). 2020; (February).

5. Nandakumar K. (2020). COVID-19: Emergence Spread, Possible Treatments, and Global.
Lai C, Shih T, Ko W, Tang H, Hsueh P. (2020). International Journal of Antimicrobial Agents Severe acute respiratory syndrome coronavirus 2 (SARS-CoV-2) and coronavirus disease-2019 ( COVID-19 ): The epidemic and the challenges. Int J Antimicrob Agents; 55(3):105924.

Johnson M. Wuhan. (2020). 2019 Novel Coronavirus - 2019nCoV. Mater Methods.

8. Asia S-WHO. India Situation. 2020.

9. Mahajan P, Kaushal J. (2020). Epidemic Trend of COVID-19 Transmission in India During Lockdown-1 Phase. J Community Health.

10. WHO. (2020). Novel Coronavirus Disease (COVID-19): Situation Update Report-8. World Heal Organ; (67):1-6.

11. WHO. (2020). Situation in numbers. Nov coronavirus Dis Situat Updat Report-11.;11(April):12-5

12. Report D. Karnataka State COVID-19 War Room Bangalore. 2020.

13. LOCKDOWN Extension Order Upto May 3rd 2020 MID NIGHT.pdf.

14. RD 158 TNR 2020 dated 02052020 Order.pdf.

15. DOC310520-31052020155205.pdf.

16. Affairs H.?'l'l-. 2020;

17. Laxminarayan R, Wahl B, Dudala SR, Gopal K, Mohan C, et al. (2020). Epidemiology and transmission dynamics of COVID-19 in two Indian states. medRxiv;697:691-697

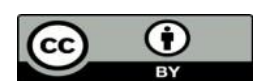

This work is licensed under Creative Commons Attribution 4.0 License

\section{To Submit Your Article Click Here: Submit Manuscript}

DOI: $10.31579 / 2690-8808 / 075$
Ready to submit your research? Choose Auctores and benefit from:

*ast, convenient online submission
* rigorous peer review by experienced research in your field
*apid publication on acceptance
* authors retain copyrights
* imique DOI for all articles
immediate, unrestricted online access

At Auctores, research is always in progress.

Learn more www.auctoresonline.org/journals/journal-of-clinical-casereports-and-studies 